\title{
Crafting connections: maya linkages between Guatemala's Altiplano and El Norte
}

\author{
MichelleJ. Moran-Taylor*
}

\begin{abstract}
International migration constitutesoneof themostsignificantphenomenaimpacting Gua temala today. A bout a million and a half Guatemalansliveand work in rural and urban cities and towns acrosstheUnited States and Canada. Likemany other migrant groups, most Guatemalans sustain strong transnational linkages between their homeland and el norte (theUnited States). In the Guatemalan examplehighlighted in this article, such bonds owemuch to thelong-standing Guatemalan-U.S. historical connections, to thecountry's geographic priximity to theU nited States. Drawing on ethnographic material, this articleexamines the divergent kinds of transnational connections that Maya indigenous ( $\mathrm{K}$ 'iche') migrants craft and keep alivebetween their home community and their two primary destination local itiesin theUnited States-Houston, Texasand LoS Angeles, California. Theartideshowsthedifferentmeans of communication and technology, as well asthevarying types of transnational organizing - particularly grass-rootsefforts- thathelp shape current linkages between thosewhogo and thosewho stay.

Keyword: Transnational migration, social ties, Guatemalan Mayamigration, communications, grassrootsorganizing.
\end{abstract}

Resumen. Lamigración internacional constituyeuno delosfenómenosmássignificativosqueafectan aGuatemalahoy en día. Casi un millón y medio deguatemaltecosviven y trabajan en grandesciudadesoen comunidades ruralesy pueblosdelosEstados Unidosy Canadá. Al igual quemuchosotros gruposmigrantes, lamayoría delos guatemaltecos mantienen fuertes lazos entresu paísnatal y $\mathrm{e}$ norte(losEstados Unidos). Según el ejemplo queseresalta en esteartículo, dichoslazos sedeben en gran medida: alasconexioneshistóricasquesehan mantenidoentreGuatemalay losEstadosUnidos desdehacemuchosaños, aladisponibilidad hoy en díademedios decomunicación y detransporte máseficientes, y ala proximidad geográficadel paíscentroamericano con losEstadosUnidos. Mediantelarecopilación dematerial etngráfico, esteartículo examinarálostipos divergentesdeconexiones transnacionalesquelosindígenas migrantes mayas ( $K$ îche') establecen y mantienen vivas entresu paísnatal y losdosdestinos principalesubicadosen losEstadosUnidos: Houston, Texasy LosÁngeles, California. Esteartículo muestralos diferentes medios decomunicación y tecnología. así como los diversostipos deorganizadionestransnacionales, principalmentelosesfuerzospor conservar susraíces, queeslo queayudaaconformar loslazos entrelosquesevan y losquesequedan.

Palabras clave: Migración transnacional, redes sociales, migración deguatemaltecos maya, comunicaiones, organización anivel local.

* Department of Geography, University of Denver. E-mail: mmoranta@du.edu 


\section{Introduction}

International migration constitutes one of the most significant social, cultural, and economic phenomena impacting Guatemala today. The mass movement to the United States has grown rapidly in the last three decades, creating a migration consciousness that penetrates just about every corner of Guatemalan society. Now nearly a million and a half Guatemalans live and work in the United States and Canada. This figure represents almost ten to fifteen percent of the total Guatemalan population. Like many other migrant groups, most Guatemalans sustain strong transnational linkages between their homeland and el norte (the United States). Certainly, these bonds owe much to the long-standing Guatemalan-U.S. historical connections, to the more efficient means of communication and transportation available, and to the country's geographic proximity to theUnited States. Whileonly one country (M exico) separates Guatemala from the United States, this spatial distance is relatively small comparable to that of other migrant sending regions. A dditionally, because of Guatemala's geographic proximity to theU.S.-M exican border, it is precisely the border straddling between Guatemala and Mexico that has recently becomethegateway to many other migrant nationals (e.g., Salvadorans, Hondurans, Ecuadorians, Chinese). Importantly, transnational attachments emergeand endure because migration in one way or another impacts those who remain behind-and in Guatemala, few remain untouched.

In this article, I examine the flow to the United States of Maya indigenous migrants from themunicipio of San Cristóbal Totonicapán in the western highlands of Guatemala. ${ }^{1} \mathrm{~A}$ focus on this group is significant because they form part of a large U.S.-bound Guatemalan migrant stream, and in turn, the increasing Latino community in the United States. Of particular concern in this paper are thekinds of transnational ties Guatemalans craft. As others observe (e.g., Glick Schiller, 1992; Kearney, 1995), transnational migration emphasizes thebi-directional

\footnotetext{
${ }^{1}$ Hereafter I refer to this town simply as San Cristóbal.
} 
flow of people, commodities, ideas, and behavior. Though we now have a clearer understanding of northbound and southbound exchanges, how these unfold from the ground up needs more attention. Here, then, I attend to transnational connections between migrants and non-migrants and their inner workings, especially from the perspective of thesending community. I show, for instance, how different means of communication facilitatethemaintenance of social ties across international borders and the varied ways in which Maya migrants keep their loyalties oriented towards their homeland. In particular, I illustrate this through theformation of migrant formal and informal organizations. Following Guarnizo and Smith (1998:29), I seek to capture how "transnationalism from below" develops in Guatemal an communities of origin. In other words, instead of looking at broader structures and exploring how migration unfolds at the statelevel, transnational frombelow illuminates theeveryday grounded activities and practices of people in migration processes and practices.

\section{G uatemalan migration studies}

Past studies that address the migratory movement of Guatemalans highlight the internally displaced population in Guatemala and the refugee problem in M exico and theUnited States (e.g., Carmack, 1988; Manz, 1988; Stepputat, 1994; Nolin Hanlon, 1999; Taylor, 1998). More recently, research that looks at Guatemalan migration to el norte typically examines how individuals adapt in their places of arrival and the new communities migrants create. Studies address how Guatemalans work and live in U.S. localities stretching across a gamut of places. Most of these works concentrate on U.S. urban places with large Guatemalan populations such as Houston (Hagan, 1994); Los Angeles (Kopahl, 1998; Popkin, 1999; Chinchilla and Hamilton, 1999; Menjívar, 1999; Hamilton and Stol t Chinchilla, 2001); Phoenix (MoranTaylor and Menjívar, n.d.); San Francisco (e.g., Vlach, 1992); and Washington D. C. (Repak, 1995). Research that centers on U.S. rural localities reveals how many Guatemalans engage in agricultural labor in Florida (Burns, 1993; Wellmeier, 1998) and work in poultry factories in N orth Carolina (Fink, 2003). In comparison to this growing body of work, 
from the view of the community of origin we know much less about this Guatemalan migration to el norte.

More specifically, limited research focuses on Guatemalan transnational migration. Transnational work examines gender in migrants' destination (Kopahl, 1998), identity formation in the context of social organizations (Popkin, 1999); attachments to land and exile (Montejo, 1999); transnational ruptures and political violence (Nolin Hanlon, 2000), and more recently, land, ethnic and gender relations in homecommunities (Taylor, Moran-Taylor, and Rodman-Ruiz forthcoming). While thesestudies provide fuller understandings of Guatemalan migration, how thoseabroad and thoseathomecraft transnational connections at alocalized-level receives less attention.

\section{G uatemala's altiplano}

Guatemala's altiplano or western highlands are known as tierra fría (cold country). ${ }^{2}$ In contrast to the rest of the country -a society generally viewed in dichotomous terms of indigenous and non-indigenousMaya people and culture dominatethealtiplano. Three factors characterize Maya culture -land, community, and affinity to place (Lovell, 1988). As Lovell (1988:27) dearly states, "this trinity has been, and will remain, fundamental to themaintenance of Maya identity." Similarly, Montejo (1999), in his writing about Maya migrants living in the United States, echoes that land, community, and affinity to place continue to form an integral part of Maya culture.

To contextual ize Guatemala's western highlands and to better understand indigenous life in this region, in what follows I sketch out a brief description of Maya identity, the role of the state, and the colonial heritage. Guatemala, and Mesoamerica in general, is often rendered as a "heritage of conquest" because of a 500-year history of conquest, repression, and marginalization (Tax, 1952; Kendall, Hawkins and Bossen, 1983; Lovell, 1988). Guatemala's altiplano is home to the

2 In Adams' (1970) regional division, the O ccidente is described as including seven departments West of Guatemala City. 
largest concentration of indigenous peoplein theNew World. Butcalculating theindigenous percentage of the Guatemalan population is a contentiousissue. Ethnic self-identity, for example, was only employed for the first time in 1994. ${ }^{3}$ Previously, as Watanabe (2000) observes, census takers (i.e., government employees) sought to discern ethnic identity in both inadequate and insensitive manners. Simply, census takers asked: “Are you Indian?” This approach, however, largely ignores the subtleties of how Guatemalans self-identify (Watanabe, 2000). From an historical perspective, Lovell and Lutz (1994) argue that regardless of current debates that address Maya populations, the sheer numbers and impressiveincrease in indigenous peoplesincethe Conquest belittle controversies about whether Mayas or Ladinos (nonindigenous) make up the majority. In short, assessing Maya demographics is a complex task. But more importantly, it embodies an issue at the heart of rethinking the nation-state in Guatemala (see Smith, 1990; Grandin, 1999; N elson, 1999; Watanabe, 2000). ${ }^{4}$ This concern emerges, particularly among some non-indigenous people, who view that as long as the Maya retain their own ethnic identity, the country cannot fully attain thestatus of a modern nation (Smith, 1990). And a modern nation state implies, Smith (1990:5) writes, "not only unity, but theeradication of what they believeto bethevery symbol of backwardness-a group of peoplestill rooted in thetraditions of a colonial past." In sum, altogether, twenty-one different ethno-linguistic groups exist in Guatemala. In recent years, however, political and economic instability has pushed an increasing number of Maya men and women from Mexico and Guatemala to the United States. Now sizeable indigenous Maya communities span the United States (seeBurns, 1993; M oran-Taylor and Richardson, 1993; Hagan, 1994; Wellmeier, 1998; Popkin, 1999; Adler, 2000; Loucky and Moors, 2000; Fink, 2003).

\footnotetext{
${ }^{3}$ While the 1994 Census contains broader information previously lacking, overall Guatemalan scholars and others criticize it for being highly flawed.

${ }^{4}$ For other discussions of Guatemalan contemporary demography, see John Early (1982, 1983). For an historical account of the demographic ramifications of the Spanish Conquest on Guatemala, see Lovell (1992) and Carmack et al. (1982).
} 


\section{San C ristóbal}

The municipio of San Cristóbal is in the heartland of Maya K'iche' indigenous culture in Guatemala's altiplano. The Maya K'iche' comprise thelargest out of thetwenty-one different Maya-speaking indigenous groups found in Guatemala. San Cristóbal lies in the midst of Guatemala's most densely populated indigenous highlands. The municipio of San Cristóbal is located within the jurisdiction of the department of Totonicapán-an area with the highest concentration of indigenous peoplein Guatemal a (approximately 97 percent [G uatemala: La Fuerza Incluyente del $D$ esarrollo H umano [UN ], 2000]). Thetown rests in between the Sija and Sal amá Rivers, at 2,330 meters above sea level in the altiplano. It sits strategically at the bustling Cuatro Caminos, the most important junction in the western highlands along the Panamerican highway. Geographically, the town is merely a 15-kilometer ride to Quetzaltenango (Guatemala's second largest city) and 185 kilometers from Guatemala City. In 1994, the municipio's population figured an estimated 29,903 (Instituto N acional deE stadística, 1994) of which 78 percent identified as indigenous (M unicipalidad de San Cristóbal, Censo U rbano, 1998).

Two crucial features earmark Maya ethnic identity: language and traje (traditional clothing). Many Maya, especially women, wear their traje. Whilemen abandoned this tradition several decades ago, women

\section{Table 1}

Population of San Cristóbal, Totonicapán

\begin{tabular}{ccc}
\hline Year & $\begin{array}{c}\text { Population } \\
\text { Town }\end{array}$ & $\begin{array}{c}\text { Population } \\
\text { M unicipio }\end{array}$ \\
\hline 1955 & 3,820 & 11,099 \\
1964 & 3,188 & 14,811 \\
1973 & 3,942 & 16,795 \\
1994 & 4,378 & 29,903 \\
\hline
\end{tabular}

Source: Instituto N acional de Estadísticas (INE), Censo de Población. De Gall (1978). 
maintain their colorful regional traje, which consists of an ankle-length corte (skirt) worn today wrapped around the waist and held with a faja (belt). Women also wear a huipil (traditional blouse). The corteremains an integral ethnic marker of the Maya K'iche' group (one announcing ethnic affiliation and geographic location). In contrast, the huipiles worn originate from various Maya regions. These traditional blouses are usually brought in the area by comerciantes (vendors) and sold at local markets. For San Cristobaleños (and for Maya groups in general) thetrajeallowsfor a shared ethnic identity. In addition to traje, Maya ethnic identity is also marked by language. Although most indigenous people in San Cristóbal speak K'iche', as well as Spanish, youngsters are slowly losing their ability to speak their native language. While doing fieldwork, for example, I observed that in a local preschool, a mere handful out of seventeen youngsters, were completely bilingual-the others spoke only Spanish. In the surrounding villages, however, a different scenario emerges. Men tend to belargely bilingual, but women typically command only a partial or no understanding of Spanish.

With respect to out-migration, the flow that emerges from San Cristóbal heading to the United States is mostly male-dominated. Though some women hail North, typically theseare females who join their husbands who migrate first. That is, the out-migration from the Maya town of San Cristóbal resembles a step migration paralleling earlier Mexican flows to el norte. Many of thesemigrants arrive to the southern U.S. metropolis of Houston, Texas (Moran-Taylor and Richardson, 1993; Rodríguez and Hagan, 2000). WhileH ouston represents a prime U.S. destination, many others go to Los Angeles, California. And, in outlying Maya villages of San Cristóbal, men and women generally gravitate to Miami, Florida.

\section{Context of exit}

Overlapping political, economic, environmental, cultural, and/ or individualistic (e.g., domestic violence) forces shape the decisions of Guatemalans to emigrate. Castillo (1999) points out that according to U.S. and M exican census data and immigration records, Guatemalan 
migration to the United States gradually emerged in the 1960s, but with the civil war escalated in the mid-1980s. By the 1990s, however, this stream of mainly undocumented migrants became a major concern for both Mexico and the United States (Castillo, 1999). Outmigration from Guatemala to the United States in the 1990s increased dueto political strife, poverty, scarcity of employment opportunities in both rural and urban areas, and the country's persistent inequalities in wealth and land ownership. This northward emigration, as Lovell (1999) observes, will continue to increase in light of the lack of alternatives to population pressure on land resources.

Although many regions in thealtiplano suffered a great deal of atrocities due to Guatemala's most repressiveyears of armed conflict in the 1980s, the department of Totonicapán (thearea whereSan Cristóbal is located) did not endure the same level of state terror its neighbors experienced. The turmoil and obliteration of entire communities that many others lived in departments such as Huehuetenango and Quiché, led thousands of Guatemalans to seek haven in Mexico and Belize; others continued further north unto the United States and Canada (see Burns, 1993; Popkin, 1999; Loucky and Moors, 2000; Nolin Hanlon, 2000). In part, residents of the department of Totonicapán did not experiencemuch of theinstitutionalized violencewrought in other heavily populated indigenous places because, as locals stold me, peoplein this particular area successfully employed their "poder local" (local power) to subvert any uprisings.

Current figures from a 1998 United Nations study in Guatemala (Guatemala: La Fuerza Incluyentedel D esarrollo H umano [UN ] 2000) clearly point to the miserable conditions prevalent for the majority of people in the country. For instance, more than half the population (57 percent) lives bel ow the international poverty line of U.S.\$2 per day. Of these six million people who fall under this poverty category, 2.8 million live in extreme poverty-that is, they fail to meet the caloric intake of the Guatemalan canasta básica (basic basket). ${ }^{5}$ Poverty, however,

${ }^{5}$ A ccording to the Instituto de Estadísticas E conómicas (2002), the canasta básica for a Guatemalan family of 5.3 consists of the following items: sour cream, cheese, fresh milk, powdered milk, chicken, beef, medium-size eggs, black beans, second-class 
is more pervasiveamong Guatemala's Maya indigenous population70 percent of indigenous people versus 41 percent of non-indigenous are classified as poor. Further, the informal economy of Guatemala accounts for 40 percent of the workforce, while 27 percent rely on subsistence agriculture, 15 percent work in the formal sector, and 12 percent hold jobs in modern agriculture. Lastly, 3.7 percent of the economically active population remains unemployed (Guatemala: La Fuerza Incluyentedel D esarrollo H umano [UN ] 2000:41-59). The lack of a comprehensive rural development policy ( 60 percent of Guatemala's population is rural) exacerbates the country's unemployment and underemployment situation and helps explain high rates of poverty in Guatemala (Jonas, 2000). Under Guatemal a's poor and tattered economic umbrella, not surprisingly, many citizens migrateto the United States seeking better opportunities and greater financial stability. As Pablo, a campesino from San Cristóbal, told me: "If we have to work here [Guatemala] like mules for pennies, why not do it el sewhere for human wages."6

\section{Methods}

This study draws on ethnographic material that forms part of a larger cross-regional and cross-cultural research project that looks at U.S.bound Guatemalan migration, more specifically, return migration, transnational processes, gender and migration, and the tangible and intangible impacts that this flow brings about in sending communities. I carried out field research in Guatemal a from 1999 through 2001 (for a total of 15 months) and employed a variety of methods such as

rice, tortillas, whitebread (pan francés), sweet bread (pan dulce), pasta for soups, sugar, butter, cooking oil, mirlitons (güisquiles), green beans, tomatoes, onions, potatoes, bananas, plantains, coffee, salt, and sodas. These comestibles, however, represent food items gleaned from a study conducted in 1983. To date, no other study assesses the specifics of what the Guatemalan canasta básica includes. Further, the current value of the canasta básica "alimentaria" (food consumption), as of July 2002, is Q1,251.42 (U.S. \$163) and the canasta básica "vital" (vital), which includes expenses such as electricity, water, telephone, and education is Q2,283.61 (U.S.\$297).

${ }^{6}$ For confidentiality purposes, throughout this article I use pseudonyms. 
participant observation, informal interviews, and in-depth semi-structured interviews. In addition to my fieldnotes, personal journal, and multipleinformal interviews, I employ data gleaned from 20 in-depth, semi-structured interviews I conducted in San Cristóbal. ${ }^{7}$ Using snowball sampling, I interviewed 10 females and 10 males (migrants and non-migrants) from a variety of socio-economic backgrounds. And of these study participants 12 were married, 8 single, 1 separated, and 1 widowed. Most people I interviewed had children-only 5 out of 15 did not. Theage of participants ranged from 20 to 82 . The occupations widely varied from weavers, artisans, seamstresses, tailors, nurses, students, entrepreneurs, and the unemployed to NGo workers. Eight of the 20 study participants were returnees-mostly males who spent on average four years in the Texan city of Houston and returned in the last five to eight years to their home community.

I interviewed San Cristobaleños in houses, tienditas (small shops), sport facilities, car, welding, clothing, and tailor shops, fields, restaurants, pharmacies, funeral parlors, churches, and NGO's. All my interviews followed a simple guide and al ways included questions about: migration and employment histories; return migration; gender relations, roles, and identity; self-identity (e.g., attitudes and perceptions of ethnic identity); transnational flows (e.g., tangible and intangible and their frequency, density, and types); migration-related changes, and future migrants' goals. This format let migrants speak freely and widely. I conducted my interviews in Spanish and not Kiche'. In urban San Cristóbal, most community members speak both languages and felt at ease using Spanish.

\section{Local-level driven transnational ties}

In particular, this section examines dimensions important in discussions that explore "transnationalism from below" and its relationship to social ties. First, I focus on the means of communications connect-

\footnotetext{
${ }^{7}$ I recorded over 500 pages of single-spaced typewritten notes that I thematically coded for analysis.
} 
ing Guatemalans with those abroad. Looking at how transnational ties emerge and are encouraged between those who stay and those who go al so requires an examination of Guatemal an hometown associations, informal organizations and migrant leadership. Carving out transnational ties becomes easier with the innovative and efficient kinds of transportation, telecommunications, and technology availabletoday. For instance, with cheaper technology, increasing purchasing power (among morefinancially prosperous individuals and those who remain behind and receive remittances), and with greater global flows and consumption of televisions, stereos, video recorders, cameras, cellular telephones, and cassette recorders-electronics become common features in many Guatemalan households. In turn, many of these commodities allow for documenting and reproducing images of daily life and celebrations, and at the same time, enable thestream, coordinated exchange, and sharing of meaningful moments, ideas, and beliefs between those abroad and those at home. When writing about globalization and its cultural dimensions, Appadurai (1996) argues that the growth of complex links between theglobal (e.g., telecommunications, technology) and thelocal constitutes one of themost distinguishing aspects of contemporary life. Bailey, Wright, Mountz, and Miyares (2002), however, critiquethis notion and call for paying more attention to how these flows may indeed be mediated in and by specific local contexts. In what follows I explore some of these concerns.

\section{Communications connecting guatemalans at home and abroad}

While Guatemala's spatial proximity to the United States helps perpetuate close-knit linkages between migrants and non-migrants, modern and easily accessible communications between migrants' places of origin and arrival undoubtedly also help ease social ties and how locals now stay connected (e.g., e-mail, cellular tel ephones, audio-cassettes, newspapers on-line, private courier services). When out-migration increased during the early 1990s in Guatemala, a proliferation of private postal services emerged linking Guatemalans with kin and friends living abroad such as Urgente Express, King Express, Intercapitales, and Gigante Express. Primarily, these private mail services 
propagated due to the inefficiency of the Guatemalan Post, high incidence of corruption behind this institution, and its failure to meet the needs and demands of many peoplethroughout thecountry. To amend its past murky image, and in accordance to Guatemala's recent move to privatizeformer government-run services, theCanada Post currently operates thenational post office (a deal it recently struck with the Guatemalan government).

Less prominent, but yet another mode of communication employed to meet recent demands and to stay connected even more efficiently include the host of private postal services now available in Guatemala City. These newer businesses offer Guatemalans a postal box address in the United States-typically in Miami, Florida, which are then forwarded to a special box in Guatemala. Certainly, paying for this service provides a safer and more private way of receiving goods and letters. Fees, however, are steep. Usually clients pay between U.S.\$15 to 20 per month to rent theforeign postal box, plus any added charges to receive packages in Guatemala.

Whilein the past, written correspondencestood as the chief modeto exchange information and to keep in touch, presently most Guatemalans favor communicating via telephone. A gain, this communication is made easier particularly following theprivatization of yet another Guatemalan entity, GUATEL-Guatemala's national tel ephone company. Whereas in other rural areas telephones are widely common, this appears less so in San Cristóbal. A mong San Cristobaleños who own a telephone, some set up teléfonos comunitarios (telephones rented out from peoples' homes, typically these include some makeshift cabin for greater privacy). Teléfonos comunitarios are useful because these allow people to better arrange when and where to call their kin or more common, to receive tel ephone calls from loved ones abroad.

Takethecase of Lupeand Juan. Though Lupeis a San Cristobaleña non-migrant, married woman in her late forties, her husband Juan returned from Houston, Texas ten years ago after living in that city for nearly two years. Both Lupeand Juan work outside of their homeshe is a teacher and he is a refrigerator technician. Through thegraces of Juan's hard work in Houston, the couple managed to expand and remodel their humblehome, and in the process, installed a telephone 
line in their front room. N ow the couple offers San Cristobal eños the services of their teléfono comunitario. While many locals in town employ such means of communications to stay connected, the couple's chief customers constitute folks from nearby villages.

Additionally, with the great influx of cellular phones in GuatemaIan households, communicating via thesemeans becomes much easier and economical than arranging to have an actual telephone line installed. Even in remote, rural villagesfor someowning a cellular phone increasingly becomes a standard feature in their homes. In these instances, kin abroad assist relatives by remitting monies to pay for the actual telephone and subsequent costs. Telephone cards or charging telephoneminutes on credit cards provides yet another avenueto more easily communicate. This mode is cheaper than having a telephone line installed at home or buying a cellular tel ephone.

A nother well-used conduit for the exchange of information among some Guatemalans communicating across borders areaudio cassettes, particularly in the western highlands. ${ }^{8} \mathrm{~A} n$ attendant at a local courier private business in San Cristóbal told me that on average during the main market day on Sundays, locals usually send around 50 to 60 audio tapes to rel atives scattered throughout the United States. In San Cristóbal, people in town and in rural areas favor forwarding audiocassettes instead of letters. This preferenceemerges dueto several reasons: 1) Their ancestral oral traditions facilitate story telling on audio tapes, 2) audio tapes are less expensivethan videos or telephonecalls, 3) it provides an avenue in which people can convey in great detail their daily rhythms, and 4) it al lows illiterate people to communicate with ease.

A final observation with regards to transnational ties, communications, and technology, concerns theways in which compatriots abroad continue to participate in their home country's affairs via national

${ }^{8}$ Rodriguez and Hagan (2000) and Ochoa (2001) make similar observations. Further, Siems (1992) brings to the fore compelling personal letters of Mexican and Central Americans. In this endeavor, he provides another perspective on the struggles and hardships that undocumented Latino migrants often encounter in the United States. 
newspapers. Since several major circulating Guatemalan newspapers can now be read on line (e.g., Prensa Libre, Siglo XXI), this medium plays an enormous rolein how Guatemal ans abroad havetheir voices heard at home-whether it is simply to wish a relative happy birthday or to critique the government in daily editorials. Below I turn attention to transnational organizing, particularly to the divergent kinds of groups and associations that enable dense linkages between Guatemala's altiplano and el norte.

Guatemalan hometown associations, informal organizations, and migrant leadership

Increasingly, transnational ties areencouraged and becomereinforced through practices at the grass-roots level. Guatemalans in the United States participate in hometown associations, sport-based organizations (primarily soccer), and church-based groups that help sustain transnational bonds between migrants' homeland and their adoptive country (Popkin, 1999; H amilton and Chinchilla, 1999; Popkin, 1999; Wellmeier, 1998; Rodríguez and Hagan, 2000; Menjívar, 2002). ${ }^{9}$ Generally, these organizations are formed by a group of people from the samecommunity of origin and migrants with shared ethnicidentities. ${ }^{10}$ But, for the most part, these organizations cut across gender, generational, and class boundaries. A key featureevident in most Guatemalan groups in the United States is that the organizations formed provide a social arena for collecting funds to send to their communities of origin (a practiceevident in many other Latino migrant groups).

\footnotetext{
${ }^{9}$ Past studies examining formal and informal associations reveal that these organizations generally function as an "adaptive mechanism in situations of rapid change undergone by urban migrants from peasant and tribal societies," but also help strengthen "the consciousness of a culture of origin and reproduce aspects of traditional institutional order in a new, urban oriented form" (Sassen-Koob, 1979:314-315).

${ }^{10}$ In contrast, N agengast and Kearney (1990) observethat pan-Mixtec transnational associations formed in the United States crosscut migrants' places of origin and instead basethemselves on a shared ethnicity. Theseassociations promotedevelopment projects along with concerns dealing with discrimination, exploitation, and human rights abuses in Mixtec enclaves found in California and Oregon.
} 
That is, the organizations look for beneficial ways to impact and change their home communities through a wide range of transnational activities and relations.

Hometown associations are successful when they depend on solidarity and strong leadership among compatriots in their places of arrival. Though in recent years hometown associations and other informal organizations emerged in U.S. localities with large Guatemalan populations (e.g., Los A ngeles, Miami, Houston, Chicago, Florida, Las Vegas), as a whole, Guatemalan migrants lack strong leadership in theUnited States. This absence is particularly truewhen compared to Salvadorans, who since the onset of their civil war (1979-1992) strived to maintain powerful leadership roles in the United States. Some Salvadorans, for instance, worked to be eligible since 1990 for the Temporary Provision Status (TPS)-a legal provision in U.S. immigration policy that calls for granting temporary refuge to undocumented migrants who fled their places of origin due to turmoil until it is safe and feasible for them to return to their home countries. ${ }^{11}$ And, because of Salvadorans' past political and economic acumen, they now count with both transnational economic enterprises and transnational political practices associated with their migrant populations in various U.S. cities (Landolt, Autler, and Baires, 1999).

When discussing the lack of Guatemalan leadership and support migrants often encounter in the United States, an informant echoed, "es que el que no chilla no mama," (he/ she who doesn't cry doesn't eat [nurse]). Specifically in this case, this refrain refers to how Guatemalans working for a number of years without legal documentation (or qual ifying to apply for U.S. residency status) in the United States fail to persuade U.S. immigration policy makers to respond in their favor. ${ }^{12}$ This outcome also reveals the kinds of structural bureaucratic issues some migrants in the United States must contend.

\footnotetext{
${ }^{11}$ For a recent provocative discussion of how provisions such as TPS in U.S. immigration policy (re)produce Salvadoran transnational geographies see Bailey et al. (2002).

${ }^{12}$ A nother exampleillustrating the previous absence of powerful support for Guatemalans in the United States concerns the number of immigration agencies (e.g.,
} 
For example, migrant Guatemalan leaders in the United States echo that despitethat they now comprise a representativegroup in theUnited States and that remittances sent back home sustain Guatemala's economy government officials (in this country and back home) do not provide the needed support-at the individual level or collectively towards the migrant organizations formed in the United States. Recently, in Miami, Florida, the president of the "Coalición de M igrantes Guatemaltecos" (Guatemalan Migrant Coalition) made a plea to the Guatemalan government to take action in designing policies to help solve migratory concerns in the United States. While the Salvadoran migrant population through hometown associations set aside $\$ 250,000$ to support their needs, particularly legal issues, this sort of action remains absent among Guatemalans (Prensa Libre, 2003). Echoing such viewsis thefollowing commentary a Guatemalan woman recently wrote in Prensa Libre (Guatemala's major circulating newspaper):

Estoy muy contenta que se dé a conocer lo importante que somos para la economía guatemalteca todos los que vivimos en USA buscando las oportunidades que en nuestro país no encontramos porque la corrupción no le deja el espacio a personas trabajadoras con deseos de superar. Yo quiero que todos los guatemaltecos sepan que de la forma que somos tratados aquí por medio de las personas que trabajan en los CONSULADOS GUATEMALTECOS es una vergüenza, nos tratan muy mal y hay que hacer algo sobre eso. Si somos importantes para la economía guatemalteca ¿POR QUÉ NO SE HACE ALGO PARA QUE NOS TRATEN COMO SERES HUMANOS? Me estoy refiriendo al consulado de NEW YORK (Prensa Libre, April 30, 2003).

I am very happy that it is made known how important weare to the Guatemalan economy all of us who live herein theU.S.

the Central American Resource Center [CARECEN] and El Rescate) that mostly catered to the Salvadoran population in Los Angeles. Later, these agencies also assisted Guatemalans. To fill this needed void, finally in 1997 the Guatemalan Unity Information Agency (GUIA), a non-profit organization dealing with immigration services in Los Angeles, emerged (Popkin, 1999). 
searching for opportunities that in our country we can't find because corruption doesn't leave room for hard-working people with a desire to get ahead. I want all Guatemalans to know that the way in which we are treated here through those who work in GUATEM ALAN CONSULATES is a disgrace - they treat us badly and we must do something about this. If weareso important for the Guatemalan economy WHY ISN'T SOMETHIN G DONE SO THATTHEY TREAT USLIKE HUMAN BEINGS? I am referring to the NEW YORK Consulate (Prensa Libre, A pril 30, 2003).

Such telling remarks are often heard not only abroad, but also repeatedly among those who remain at home. But again, these views can now be expressed more fully and to a larger group because of the technology and means of communications now available-indeed a feature that sets apart newer transnational migration trends from those experienced in the past. These remarks also highlight how folks can continue to participate in their home country's affairs, albeit remotely.

\section{M aya hometown associations}

To gain a better appreciation of the role that Guatemalan hometown associations, informal organizations, and migrant leadership in these groups play in crafting transnational connections, below I address the exampleof Mayan migrant organizationsformed by San Cristobaleños in the United States. Several associations, for example, especially church and sport-related ones, have emerged in H ouston, Texas. Like voluntary organizations that other Latino migrants (in Latin America and in the United States) are formed to aid community members incorporateinto their new social contexts, San Cristobal eño associations in Houston form along similar lines.

Other ways that San Cristobaleño organizations created in Houston assist their home community is particularly noted through the home community's most significant social event-the fiesta titular. This fiesta constitutes a community-wideannual celebration venerating the town's patron saint-St. Christopher. Townsfolk and those in the villages 
come together during this time to celebrate the anticipated event with much fanfare. Essentially, thefiesta titular offers community members the social space in which to symbolize the continuance of traditions, to flaunt social status and power, and to strengthen, as Lewis (1960) observes, the town's esprit de corps. Past Mesoamerican ethnographic studies that focus on Guatemala's highland Maya groups (e.g., Warren, 1978; Watanabe, 1992) highlight theimportance of patron saints and community-wide fiestas.

The fiesta titular represents one of the most striking and apparent ways in which migration impacts San Cristóbal. While in the past the cargo system-a civil-religious hierarchy in Mesoamerican communities-played a crucial rolein religiousfiesta sponsorship (Chance, 1996), today migration looms as significant. Migrants arrive days ahead in preparation of the chain of events programmed for this special occasion. Overall, migration dollars allow for a greater social and material enhancement of the fiesta. And, for those unable to make the annual trip back to their homecommunity, events arecarefully photographed and/ or documented with video cameras. In short, as Mountz and Wright (1996:416) poignantly write, "thefiestas... bring together thefruits of production if not the producers themselves." Thus, at thelocal-level, fiesta sponsorship further accentuates linkages between migrants' places origin and arrival.

Fiesta sponsorship from organizations formed in Houston, and individuals alike, promote a variety of social events scheduled during this annual cel ebration. Don Luis, a returneefrom Houston in his late forties explained, for instance, how several weeks prior to the festivity a committee in San Cristóbal, of which he belongs, will solicit funds from community membersto sponsor music bands to play in the parque (plaza) during one of the fiesta's main celebration days. Generally, he told me, his committee raises nearly Q3, 000 (U.S.\$350) from San Cristobaleños who remit part of their migrant earnings from Houston. But, when I asked don Luis about Los Angles-based groups and their sponsorship, he emphatically responded:

Look, what happens is that peopleneed to beenthusiastic with their time. Therearefolks around here [San Cristóbal] that have 
relatives and friends over there [Los Angeles], but they don't want to giveup their timeto find them, to get them to collaborate, that's why there's nobody [that sends from Los Angeles].

But perhaps what may also be at play in that membership in formal and informal organizations in Los Angeles seem less cohesive and developed in that city lies on logistics. In fact, I al so observed this pattern among Guatemalans in Phoenix, A rizona. In Houston, however, San Cristobaleños tend to cluster in apartment complexes. This settlement pattern has allowed San Cristobaleñosto maintain substantial interactions with fellow migrants and other Maya indigenous people (Hagan, 1994; Rodríguez and Hagan, 2000).

In sum, fiesta sponsorship generates a great deal of prestige, power, and purview among participants in their communities of origin and arrival. During the feria, for example, loud speakers bellow names of sponsors to throngs of people standing and swaying to the rhythms of music bands playing marimba, salsa, and merengue in San Cristóbal's parque. Further emphasizing the visibility that this cultural practice endorses involves committee organizers publidy listing the names of sponsors in the town's center. Fiesta sponsorship, then, underscores how moreestablished migrants-thoseableto afford greater material displays-gain social status and respect within and outside San Cristóbal. Put differently, they are able to "display spending power, claimstatus, and haveit valorized" (Goldring, 1998:181). Equally significant relates to how fiesta sponsorship provides the opportunity in which to reaffirm community membership and fealty (Mountz and Wright, 1996; Goldring, 1998), a practicethat hel ps enhancemigrants' social position and enhance their cultural traditions within their communities of origin.

\section{Conclusion}

This article demonstrates the multiple ways and local outcomes in which Guatemalans in the homeland and those abroad craft connections-through divergent means of communication and technology to the varying existent kinds of transnational organizing. Such 
emphasis adds to discussions on transnational ties and to how these links affect migrants' places of origin. By embracing a "transnationalism from below" perspective, this entails looking from a localized level at distinctive formal and informal organizations that emerge such as the hometown associations San Cristobaleños forge in their U.S. destinations. When examining Guatemalan hometown associations, I point to how San Cristobaleños in Houston develop similar agendas as those their country fellows create in other U.S. cities. That is, to help their community of origin towards some humanitarian need and to assist fellow migrants during dire times. In San Cristobaleño associations, for instance, people come together to aid a fellow compatriot, as in the case of providing monetary assistance to send a migrant body back home for burial in the homeland.

A most striking manner in which San Cristobaleño associations contribute towards their home community is in the fiesta titular. In San Cristóbal, sponsorship for the fiesta from thoseabroad takes place in conspicuous ways, and in part, this relates to particular Maya mores. Traditionally, the cargo system serves as a mechanism to support the religious fiesta. In accordance with the cargo system, those who reach the higher levels of the ranked system of municipal offices "are called on to make large financial sacrifices to sponsor religious fiestas" (Chance, 1996:386). But unliketheexampleof U.S.-bound migrants from Oaxaca, Mexico that captures how the cargo system and migration closely intertwine (Mount and Wright, 1996), this does not ring true in the Maya example of Guatemala. In San Cristóbal, this kind of structured fiesta sponsorship, that is, oneexpressed through cargos no longer is significant. Instead, such a cultural practiceand show of weal th unfolds in a more laissez-fairefashion. Thus, for migrants who may have at their disposal extra financial resources (or seeto haveit), fiesta sponsorship provides the means for individuals to more quickly gain visibility, greater prestige, and to display their new social status-elements, which in the past may have proven more difficult to obtain following thehierarchical cargo system. In short, Maya transnational linkages are kept alive by the divergent ways in which folks abroad and folks at homestay connected. Thetransnational organizing at work among this indigenous group parallels in many ways that of other migrant groups. 
At the sametime, the case explored here is unique because of particular Maya mores as well as the relationship to thestate.

\section{References}

Adler, Rachel. 2002. "Patron-ClientTies, Ethnic Entrepreneurship, and

Transnational Migration: The Case of Yucatecans in Dallas,

Texas". U rban A nthropology; no. 31, vol. 2, pp. 129-162.

A ppadurai, Arjun. 1996. M odernity at Large: Cultural Dimensions of Glo-

balization. University of Minnesota Press. Minneapolis.

Bailey, Adrian, et al. 2002. “(Re)producing Salvadoran Transnational

Geographies". A nnals of the A ssociation of A merican Geographers

no. 92, vol. 1, pp. 125-144.

Burns, Allan. 1993. M aya in Exile: Guatemalans in Florida. Temple Uni-

versity Press. Philadel phia.

Carmack, R., ed. 1988. Harvest of V iolence: The M aya Indians and the Guatemalan Crisis. N orman, University of Oklahoma Press.

Castillo, Manuel Angel. 1999. "Exodusand Return with a Changing Migration System". InJ ourneys of Fear: R efuge Return and N ational Trans-

formation in Guatemala. L.L. North and A. Simmons, eds. McGill-Queen's University Press. Montreal, pp. 130-154.

Chance, John. 1996. "M esoamerica's Ethnographic Past". E thnohistory no. 43, vol. 3, pp. 379-403.

Fink, Leon. 2003. The M aya of M organton: W ork and Community in the $\mathrm{N}$ uevo N ew South. Chapel Hill. University of N orth Carolina Press.

Glick Schiller, Nina, Linda Basch, and Cristina Szanton Blanc (eds.). 1992.

Towards a transnational perspectiveon migration: Race, class, ethnicity, and national ism reconsidered. New York A cademy of Sciences. New York. Volume 645.

Goldring, Luin. 1998. “The Power of Status in Transnational Social Fields". In Transnationalism from Below. M.P. Smith and L.E.

Guarnizo (eds.), Transaction Publishers. News Brunswick. vol. 6. Grandin, Greg. 2000. The Blood of Guatemala: A H istory of Race and N ation. DukeUniversity Press. Durham.

Guarnizo, Luis, and M. P. Smith. 1998. "The Locations of Transnationalism". In Transnationalism from Below. M.P. Smith and L. 
Guarnizo (eds.), pp. 3-34. Comparative Urban \& Community Research, Vol. 6. New Brunswick: Transaction Publishers. Hagan, Jaqueline. 1994. Deciding to Be Legal: A M aya Community in H ouston. TempleUniversity Press. Philadel phia.

Hamilton, Nora, and N orma Chinchilla. 1999. “Changing Networks and Alliances in a Transnational Context: Salvadoran and Guatemalan Immigrants in Southern California". Social Justice, no. 26, vol. 3, pp. 4-26.

Hamilton, Nora, and Norma Stoltz Chinchilla. 2001. Seeking Community in a Global City: Guatemalans and Salvadorans in Los Angeles. TempleUniversity Press. Philadel phia.

Instituto de Estadísticas E conómicas. 2002. Canasta Básica. Instituto $\mathrm{N}$ acional de Estadísticas. 1994. Censo de Población.

Kearney, Michael. 1995. “TheLocal and the Global: TheA nthropology of Globalization and Transnationalism". A nnual Review Anthropology, no. 24, pp. 547-65.

Kendall, Carl, John H awkins, and Laurel Bossen, eds. 1983. H eritage of Conquest, Thirty Y ears Later. University of N ew M exico Press. Albuquerque.

Kohpahl, Gabriele. 1998. Voices of Guatemalan Women in Los Angeles:

U nderstanding their Immigration (Latino Communities, Emerging V oices, Political, Social, Cultural, and Legal). Garland Publishing. New York.

Landolt, Patricia, Lilian A utler, and Sonia Baires. 1999. "From Hermano Lejano to Hermano Mayor: The Dialectics of Salvadoran Transnationalism". Ethnic and Racial Studies, no. 22, vol. 2, pp. 290-315.

Lewis, Oscar. 1960. Tepoztlán:V illagein M exico. Holt, Rinehartand Winston, Inc. Orlando.

Loucky, James and Marilyn Moors, eds. 2000. M aya in the Diaspora: Guatemalan Roots, N ew A merican Lives. TempleUniversity. Philadelphia.

Lovell, George. 1988. "Surviving Conquest: TheM aya of Guatemala in Historical Perspective". Latin A merica Research R eview, no. 23, vol. 2, pp. 25-57. 
Lovell, George. 1999. "Land and Peace: Two Points of View". In Journeys of Fear: Refuge Return and $N$ ational Transformation in Guatemala. L.L. North and A. Simmons, eds. McGill-Queen's University Press. Montreal, pp. 40-54.

Lovell, George and Christopher Lutz. 1994. "Conquest and Population: Maya Demography in Historical Perspective". Latin A merica Research Review, no. 29, vol. 2, pp. 133-140.

Manz, Beatriz. 1998. R efugees of a Hidden W ar: The A ftermath of Counterinsurgency in Guatemala. State University of New York Press. Albany.

Menjívar, Cecilia. 1999. "TheIntersection of Work and Gender". A merican Behavioral Scientist, no. 40, vol. 4, pp. 601-627.

Montejo, Víctor. 1999. "Tied to the Land: Maya Migration, Exile, and Transnationalism". In Identities on the M ove, Transnational Process in N orth A merican and the Caribbean Basin. L. Goldin, ed. Institute for Mesoamerican Studies, University at Albany. Albany, vol. 7, pp. 185-202.

Moran-Taylor, MichelleJ., and MilesRichardson. 1993. "Placeand Journey in the Lives of Guatemal an M igrants: Documenting the Undocumented". Southern A nthropologist, no. 20, vol. 3, pp. 12-22.

Moran-Taylor, Michelle J. and Cecilia Menjívar. n.d. "Unpacking Longings of Return: Guatemalans and Salvadorans in Phoenix", A rizona. Manuscript under review. Mimeo

Mountz, Alison, and Richard Wright. 1996. "Daily Life in the

Transnational Migrant Community of San A gustin, Oaxaca, and

Poughkeepsie, N ew York". D iáspora, no. 5, vol. 3, pp. 403-427. M unicipalidad de San Cristóbal. 1998. Censo Urbano.

$\mathrm{N}$ aciones U nidas en G uatemala. 2000. Guatemala: el R ostro Rural del D esarollo H umano. Magna TerraEditores. Guatemala City.

Nagengast, Carole, and Michael Kearney. 1990. “Mixtec Ethnicity: Social Identity, Political Consciousness, and Political Activism". Latin A merican Research Review, no. 25, vol. 2, pp. 61-91.

Nelson, Diane. 1999. A finger in theW ound, Body Politics in Q uincentennial Guatemala. University of Cal ifornia Press. Berkeley.

Nolin Hanlon, Catharine. 1999. “Guatemal an refugees and returnees: Place and Maya Identity". In Journeys of Fear: R efugee R eturn and 
N ational Transformation in Guatemala. L. North and A. Simmons (eds.). McGill-Queen's Press. Montreal and Kingston, pp. 213-234. Ochoa García, Carlos. 2001. “Migraciones de un pueblo K'iche' hacia Houston". In M igration Guatemala-M exique. P. Petrich (ed.). Universitede Paris. Paris.

Popkin, Eric. 1999. "Guatemalan Mayan migration to Los Angeles: Constructing transnational linkages in the context of the settlement process". Ethnic and Racial Studies, no. 22, vol. 2, pp. 267-89. Prensa Libre. 2003. “En EE.UU. viven 1 millón 172,391 guatemal tecos". GuatemalaCity.

Repak, Terry A. Waiting on Washington: Central A merican Workers in the $N$ ation's Capital. Temple University Press. Philadelphia.

Rodríguez, Nestor and Jaqueline Hagan. 2000. “Maya Urban Villagers in Houston: The Formation of a Migrant Community from San Cristóbal Totonicapan". In TheM aya D iaspora: Guatemal an R oots, $\mathrm{N}$ ew A merican Lives. J. Loucky and M. Moors (eds.). TempleUniversity Press. Philadel phia, pp. 197-209.

Sassen-Koob, Saskia. 1979. “Formal and Informal Associations: Dominicans and Colombians in New York". International M igration Review, no. 13, vol. 2, pp. 314-332.

Siems, Larry. 1992. Between the Lines: Letters between U ndocumented M exican and Central A merican Immigrants and their Families and F riends. University of A rizona Press. Tucson.

Smith, Carol. 1990. "Class Position and Class Consciousnesss in an Indian Community: Totonicapan in the 1970s". In Guatemalan Indians and the State, 1540-1988. C. Smith (ed.). University of Texas Press. Austin, pp. 205-29.

Tax, Sol, ed. Heritage of Conquest, The Ethnology of M iddle A merica. The FreePress. Glencoe.

Taylor, Clark. Return of G uatemala's R efugees: Reweaving the Torn. Temple University Press. Philadel phia.

Taylor, Matthew, Michelle Moran-Taylor, and Debra Rodman-Ruiz Forthcoming. "Land, Ethnic, and Gender Change: Transnational Migration and itsEffects on Guatemalan Lives and Landscapes". Geoforum. 
Vlach, N orita. 1992. The Q uetzal in Flight: Guatemalan Immigrant Families in the U nited States. Praeger Publishers. San José.

Warren, Kay. 1978. TheSymbolism of Subordination: Indians in Guatemala. University of Texas Press. A ustin.

Watanabe, John. 1992. M aya Saints and Souls in a Changing W orld. University of Texas Press. Austin.

Watanabe, John. 2000. "Maya and A nthropologists in theHighlands of Guatemalasincethe1960s". In Supplement to theH andbook of M iddle A merican Indians: Ethnology. University of Texas Press. Austin, vol. 6, pp. 224-248.

Wellmeier, Nancy. 1998. Ritual, Identity, and the M ayan D iaspora. Garland Publishing, Inc. N ew York.

Artículo recibido en mayo de 2003. Segunda versión recibida en noviembre de 2003. Artículo aprobado en noviembre de 2003. 
